\title{
Uma análise geo-histórica da construção de um mito em São José dos Campos (SP) entre 1930 e 1964
}

\section{Geo-historical analysis of a myth creation in São José dos Campos (SP) from 1930 to 1964}

Valéria Zanetti, Maria Aparecida Chaves Ribeiro Papali, Sandra Maria Fonseca da Costa

Universidade do Vale do Paraíba (UNIVAP), São José dos Campos, SP, Brasil.

\section{Resumo}

A cidade de São José dos Campos, situada no Vale do Paraíba paulista, tornou-se polo industrial e tecnológico na década de 1960, quando deixou de ser estância climática destinada ao tratamento de tuberculosos. As transformações do bairro de Santana, localizado na região norte, caracterizado como primeiro bairro industrial da cidade, tornaram-se importantes para compreender a construção do mito da andarilha Maria Peregrina. Ela era uma indigente sem registro histórico que perambulou pelo bairro de Santana, entre as décadas de 1940 e 1960, e marcou significativamente a memória dos moradores. Sem provas de sua existência, busca-se entender como a andarilha passou a ser referência para o bairro e em que momento isso ocorreu. Esse estudo baseia-se na metodologia da geografia histórica, segundo proposta de Braudel, que propõe o diálogo entre as duas áreas do conhecimento, compreendendo as dimensões tempo, sujeito e espaço. Nas décadas de 1960 e 1970, o bairro de Santana, antigo espaço de morada da Peregrina, perdeu, paulatinamente, o status de bairro industrial. Nesse contexto de perda da hegemonia do bairro e transformação do espaço urbano é que o mito da andarilha Maria Peregrina cresceu entre os moradores, como forma de coesão social e reconstrução da identidade do bairro.

Palavras-chave: Planejamento urbano. Cidade. Mito. Geografia urbana.

\section{Abstract}

The city of São José dos Campos, located in the Region of Vale do Paraíba, state of São Paulo, became an industrial and technological pole since 1960's, when the city ceased to be a climatic sanatorium for the treatment of tuberculosis. The changings on the district of Santana, located in the North region of the city, that is characterized as the first industrial area of the city, became important to understand the myth of the wanderer Maria Peregrina. She was an indigent who ramble around Santana, and marked expressively the memory of the residents of this neighborhood. Without evidence of her existence, it is hard to understand how the wanderer became a reference to the neighborhood and at what time it happened. This study is based on the methodology of historical geography, as proposed by Braudel, suggesting the dialogue between the two

VZ é historiadora, doutora em História pela PUC-SP, e-mail: vzanetti@univap.br MACRP é historiadora, doutora em História pela PUC-SP, e-mail: papali@univap.br SMFC é geógrafa, doutora em Informação Espacial pela POLI-USP, e-mail: sandra@univap.br 
areas of knowledge, considering time, subject and space dimensions. The district of Santana gradually missed its status of industrial neighborhood, during 1960's and 1970's. In this context of losing its hegemony as an industrial district and transformation of urban space that the myth of the wanderer Maria Peregrina grew among residents as a form of social cohesion and reconstruction of the identity of the neighborhood.

Keywords: Urban planning. City. Myth. Urban geography.

De acordo com Campos (1992, p. 46), os setores sociais de uma cidade ficam à margem no processo de crescimento econômico de um país. Para o autor, isso acontece "[...] porque cabe às cidades, e especialmente aos poderes municipais, receber o impacto primeiro dos problemas sociais de nosso país, que é já, e cada vez mais, essencialmente urbano".

A cidade é vista como um elemento empírico, a base territorial, o ambiente construído; o urbano é o processo, a cidade representa sua dinâmica de funcionamento (Souza, 1994). Assim, para entender o crescimento de uma cidade, não se pode esquecer de avaliar o urbano, ou seja, o processo, o porquê de determinadas formas ou direções de seu crescimento. Nesse aspecto, para compreender as transformações espaciais urbanas, pode-se também utilizar da história dos mitos.

A cidade de São José dos Campos, importante polo industrial do Vale do Paraíba Paulista, assim como outras cidades, tem personagens e mitos que ajudaram a construir sua história e que podem contribuir para a compreensão da estruturação do seu espaço urbano. Nessa importante cidade industrial do Vale do Paraíba Paulista, entre as décadas de 1940 e 1960, uma andarilha perambulou incansavelmente pelas ruas do bairro de Santana, zona norte da cidade de São José dos Campos (Martins, 2011, p. 10).

De acordo com relatos de antigos moradores do bairro de Santana, alguns apresentados nesse artigo, Maria Peregrina era uma mulher reservada e compartilhava muito pouco de sua vida. Em uma tarde de 1964 foi encontrada morta, próxima à estação ferroviária do bairro, sem sinais de violência. Enterrada como indigente, a andarilha, aparentemente "sem história”, acabou, anos depois, elevada à condição de santa pelos moradores do bairro. 0 que teria levado a população do bairro a depositar na Peregrina seus votos de devoção? Quando surgiu o mito da Maria Peregrina? Por que está circunscrito apenas ao bairro de Santana, zona norte de São José dos Campos?
Procura-se elucidar essas questões com base na história do local, mais precisamente da sua geografia atrelada à história e, particularmente, à perda de referência industrial do bairro de Santana. Pretende-se pensar o mito Maria Peregrina no contexto das décadas de 1960 e 1970, relacionado ao espaço que o confortou. Trata-se não unicamente da análise da mitificação de Maria Peregrina, mas, sobretudo, de compreender o sentido que se deu ao mito com as mudanças do bairro de Santana ao longo do tempo.

Entende-se que o significado da devoção à Peregrina só pode ser compreendido se forem considerados a realidade e o contexto do espaço em que foi construído. Para isso, vale-se da metodologia da Geografia Histórica, campo que estabelece interlocução entre a Geografia e a História, segundo proposta de Fernand Braudel (apud Dosse, 2003). Braudel, que escreveu a história dos espaços, propõe o diálogo entre as duas áreas do conhecimento, compreendendo as dimensões tempo, sujeito e espaço. Esse enfoque busca recuperar o papel dos agentes sociais inscritos em um espaço geográfico situado, isso porque, segundo Braudel, "[...] uma civilização é, na base, um espaço trabalhado, organizado pelos homens e pela história" (Braudel apud Dosse, 2003, p. 201). Trata-se de utilizar a Geografia histórica como ferramenta para entender a história dos espaços, uma vez que a história das sociedades é simultaneamente temporal e espacial e o espaço se apresenta como uma estrutura da história.

Lucien Febvre, na década de 1930, em plena campanha pela renovação da historiografia francesa, "[...] convida o historiador a inspirar-se nos problemas colocados pelo tempo presente, no qual ele vive, pensa e escreve". M. Bloch (apud Dosse, 2003, p. 67-68), seguindo os ensinamentos de La Blache, apontou o caminho quando ressaltou que o historiador parte também das paisagens contemporâneas para remontar o passado. Para Moraes (1988, p. 15), “[...] a paisagem manifesta a historicidade do desenvolvimento humano, associando objetos fixados ao solo, geneticamente 
datados". Ou como decreta a frase: "O espaço é a acumulação desigual de tempos" (Santos, 2004, p. 9). 0 tempo, espacializado na paisagem, aprisiona memórias e revela histórias.

O estudo da construção do mito da Maria Peregrina compreende dois tempos históricos: o de antes de sua morte (1946 a 1964) e o post-mortem, momento em que incorpora uma gama de representações sociais, oriundas da forte tradição religiosa preponderante na região de circunscrição do mito.

Sem provas documentais de sua origem, tudo que se sabe a respeito de Maria Peregrina é fruto das tradições orais. Os que a conheceram diziam se tratar de uma moradora de rua como muitas de sua época. Em 1964, quando morreu, a andarilha foi enterrada num pequeno túmulo sem identificação no bairro de Santana (Martins, 2011). A fama da andarilha começou a ganhar proporção quatro anos após a sua morte, quando uma moradora, em agradecimento a um milagre recebido em interseção à mendiga, resolveu dar a ela um túmulo digno de acomodar uma santa (Martins, 2011). Depois desse episódio, o jazigo da andarilha passou a ser alvo de grande peregrinação. Pela ausência de dados verossímeis acerca de sua vida e origem, o pedido de canonização encaminhado pelos devotos foi vetado pela Igreja católica (Martins, 2011, p. 5).

A falta de dados confiáveis sobre a história da Maria Peregrina pareceu, em um primeiro momento, um empecilho à pesquisa. Contudo, onde faltam documentos escritos, deve o pesquisador se atentar para as fábulas, os mitos e os sonhos de imaginação. Sabe-se que onde o homem passou, onde houver as marcas da sua vida, aí está a história (Le Goff, 1990).

0 culto à Maria Peregrina revelou-se, não pela documentação histórica, mas pelo silêncio das fontes. Trata-se de uma mulher que viveu, por aproximadamente duas décadas, em uma comunidade de origem predominantemente mineira, mas que não deixou muitos registros sobre sua história. Uma coisa é certa: Maria Peregrina, em vida, jamais despertou a atenção dos pesquisadores. Entretanto, após sua morte, ao mesmo tempo que sua fama de santa milagreira se espalhou, nas décadas de 1970 e 1980, começou a surgir uma variada gama de relatos sobre sua vida (Melo, 1992; Martins \& Zanetti, 2011).

A falta de informações sobre a personagem serviu para ampliar o campo dos elementos "possíveis" dentro da narrativa, ou seja, o fato de Maria Peregrina não ter uma biografia sólida permitiu a constante reinvenção do mito, capaz de representar diferentes aspectos da sociedade na qual se originou (Martins \& Braga, 2009, p. 3).

Apesar de a história de vida da Maria Peregrina ser importante, não nos interessa comprovar sua existência. Propõe-se analisar o processo de construção da lenda por meio dos relatos elaborados após 1964, disponibilizados em fontes bibliográficas utilizadas para elaboração desse artigo, e o motivo pelo qual a comprovação de sua verossimilhança não foi, em momento algum, objeto de interesse da mitificação. Pretende-se, sobretudo, relacionar a história de construção do mito à história do bairro de Santana, antigo espaço de concentração de indústrias da primeira fase industrial do município de São José dos Campos, e entender como as características do espaço constituem representações para identificar o espaço e seus moradores.

\section{Uma breve contextualização histórica do município de São José dos Campos}

O município de São José dos Campos localiza-se no Vale do Paraíba Paulista (Figura 1), possui uma área de $1.099,66 \mathrm{~km}^{2}$ e conta com uma população urbana em torno de 700 mil habitantes, de acordo com o Censo de 2010 (IBGE, 2014). Sua sede administrativa, a cidade, tornou-se vila em 27 de julho de 1767, depois de um período como reduto de índios aldeados. Nomeada Vila de São José do Paraíba, a cidade passou, desde então, por diferentes períodos de desenvolvimento que influenciaram sua conformação urbana atual.

Sem projeção na colônia e no império, o município possui características peculiares. É o único polo regional do estado que não esteve ligado ao complexo cafeeiro, como Bananal, Areias, Silveira, Lorena, Taubaté e Jacareí.

Essa especificidade fez o município de São José dos Campos desenvolver um processo particular de organização regional, assentado exclusivamente sobre o crescimento urbano-industrial. Na década de 1920, ocorrem os primeiros avanços na industrialização, marcados pela primeira fase industrial, representados pela instalação de indústrias cerâmicas (Weiss e Bonádio), olarias e tecelagens (Tecelagem Parahyba).

Só se entende essa faceta do município, de sua evolução independente da base agrícola regional, associada ao 


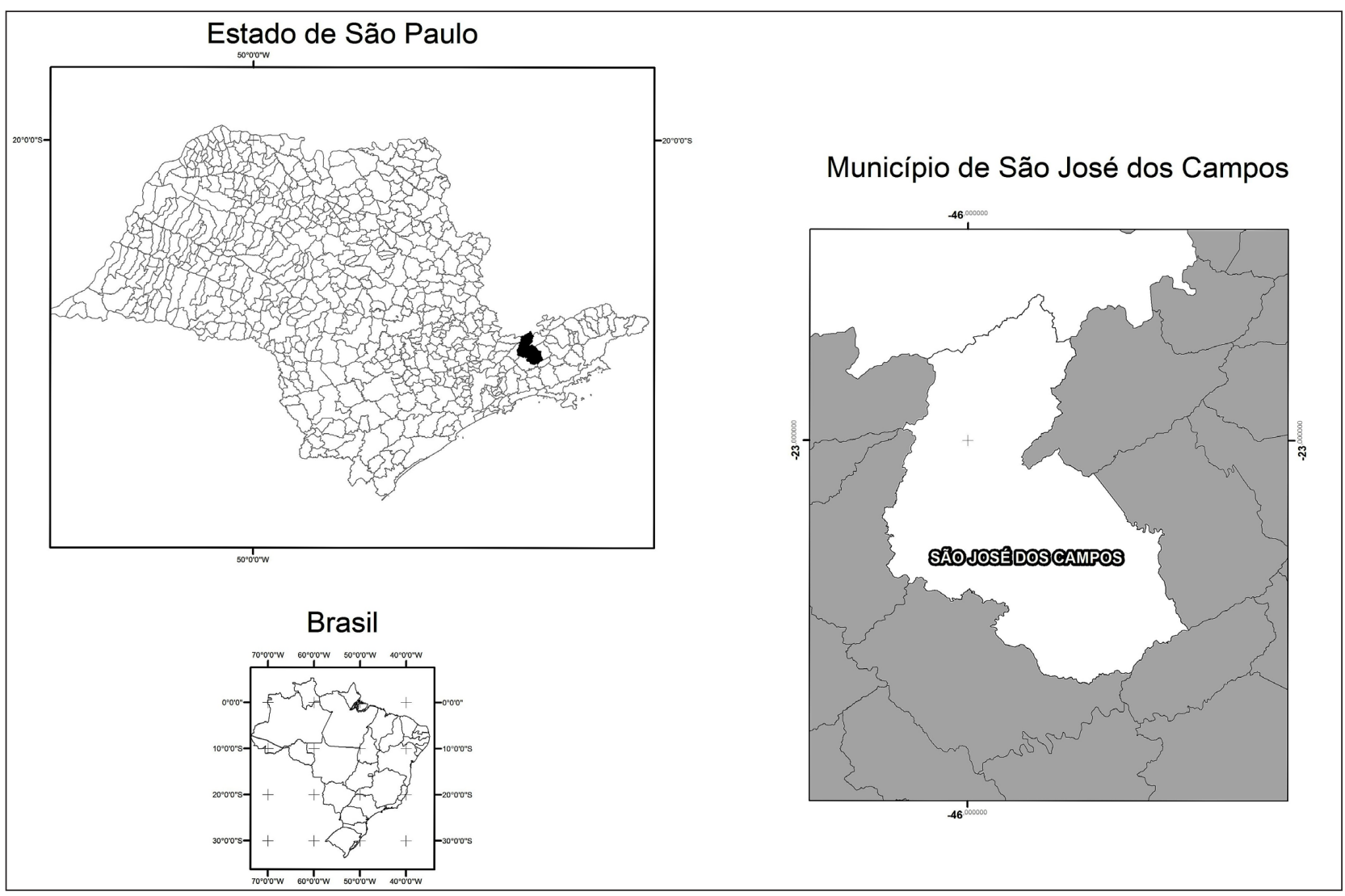

Figura 1 - Localização do município de São José dos Campos, no estado de São Paulo Fonte: elaborado pelas autoras.

processo de desconcentração industrial da capital do estado, sobretudo na década de 1950 . Os principais determinantes do processo de interiorização da indústria do estado de São Paulo, de acordo com Costa (2007, p. 32), estiveram relacionados a políticas restritivas à área metropolitana que inibiram a ampliação de novas unidades industriais; a políticas de interiorização estimuladas pelo governo federal; ao crescimento das exportações de manufaturados; a investimentos estatais no setor produtivo e no desenvolvimento da ciência e da tecnologia, com a implantação do Centro Tecnológico da Aeronáutica - CTA (1950) e da Embraer (1969), prioridades do Ministério da Aeronáutica para produzir aviões; à infraestrutura viária existe, com sistema de abastecimento de água e coleta de esgoto, entre outros.

Essa última condição foi adquirida como resultado do status sanatorial da cidade. Em 1935, passou a ser considerada uma estância climática e hidromineral com fins para o tratamento da tuberculose. Essa característica, que começou a se definir no final do século XIX e se estendeu até o final da década de 1950, permitiu que o fundo destinado à estância, "seguro obrigatório contra a tuberculose", fosse aplicado na infraestrutura urbana e nos equipamentos públicos, bases que viabilizaram a cidade industrial moderna (Zanetti, 2010).É desse período (1938) o primeiro zoneamento que dividiu a cidade em zonas: sanatorial, industrial, comercial e residencial (Figura 2).

Os equipamentos necessários ao tratamento das doenças pulmonares exigiam infraestrutura específica, o que influenciou a expansão urbana, pois foi necessário construir estações de tratamento de água e de esgoto, pavimentar ruas, construir desinfetórios, dispensários e, principalmente, remanejar pensões e sanatórios. Segundo Bittencourt (1998, p. 35),

[...] a fase sanatorial, em termos cronológicos, é simultânea ao primeiro período do processo de industrialização de São José dos Campos, tendo seu princípio com a implantação de olarias, cerâmicas e tecelagens, entre outras. 
0 fato de o bairro de Santana ter se estruturado ao redor das indústrias, enquanto outros bairros da cidade organizavam-se em torno dos sanatórios, é o ponto-chave para compreender a relação que se estabelece entre bairro-cidade. Tal relação baseia-se na clara definição das funções sociais e econômicas de cada uma das regiões da cidade.

No contexto da "São José sanatorial", a delimitação das zonas de uso tornou visível a distinção entre cidade e bairro, definindo a função social desses espaços. De acordo com Ramos (2009, p. 1):

[...] a divisão espacial como estratégia para atender as necessidades funcionais da economia do município, especificamente orientado para acolher os doentes acometidos pela tuberculose, limitou as fronteiras [...]. Definida por uma linha imaginária que separava as zonas de tratamento da tuberculose da promissora zona industrial (Santana), a política de zoneamento, ao tentar organizar e administrar a cidade segundo orientações dos modernos princípios de urbanização acabou tornando a zona industrial uma área autossustentável com fortes apelos de emancipação política, que repercute ainda hoje na memória dos habitantes do bairro.

De certa forma, a política de zoneamento urbano contribuiu para manter a sensação de isolamento do bairro de Santana em relação à cidade. Nas primeiras décadas do século XX, São José dos Campos foi uma cidade-estância cuja economia e política se articulavam em função dessa caracterização. Santana, no entanto, que não se beneficiava da condição da doença, se

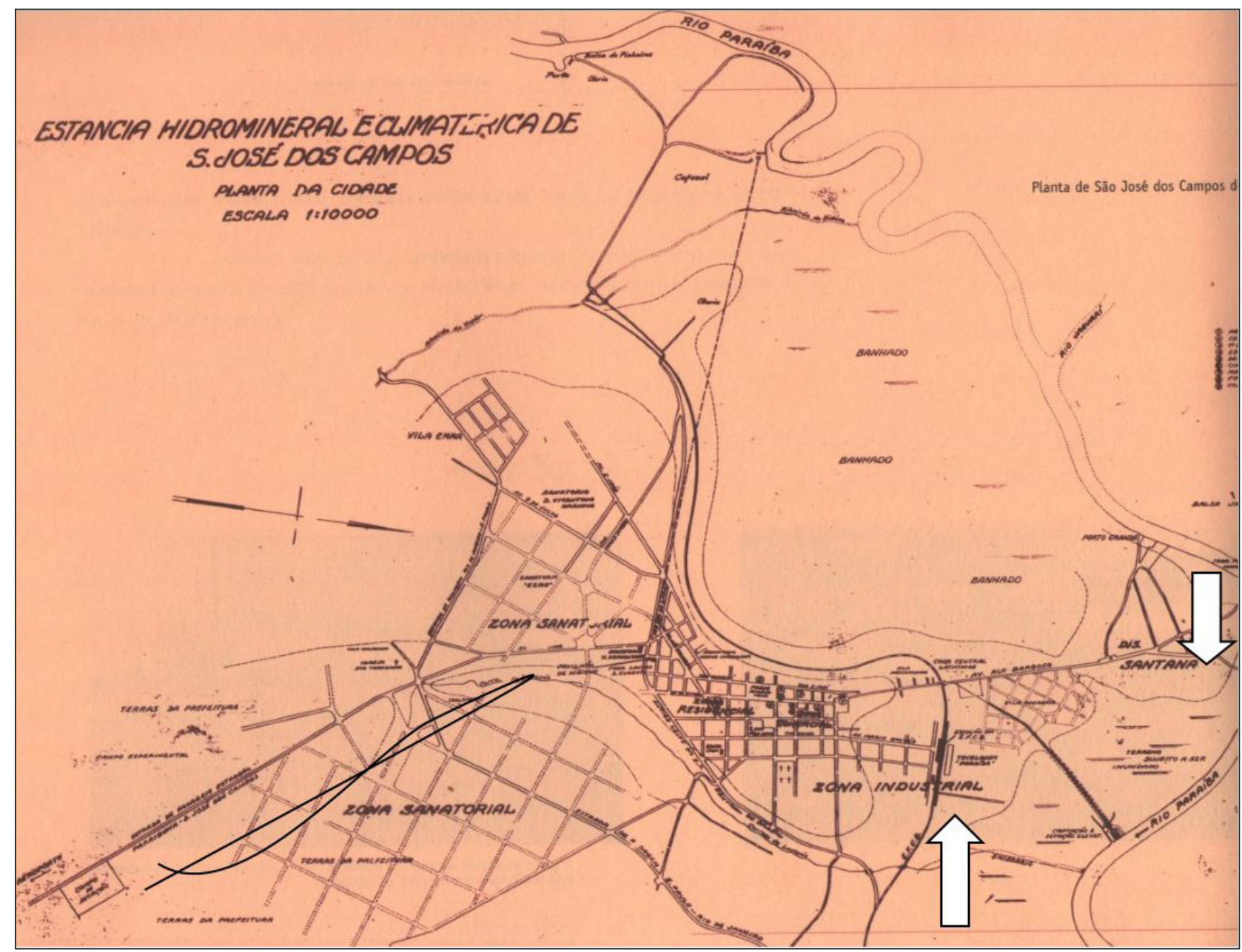

Figura 2 - Mapa do zoneamento de 1938, ressaltando-se, na seta branca, o bairro de Santana e a zona industrial de São José dos Campos Fonte: Ramos (2009). 
organizou, como foi ressaltado, em torno da função industrial.

A trajetória histórica do município tornou São José dos Campos sede de um dos mais importantes aglomerados da rede urbana paulista, destacado como um dos centros econômicos mais relevantes do estado e do Brasil. Desde a década de 1970, assumiu o papel de metrópole emergente, atraindo um grande volume de indústrias concentradas ao longo da Rodovia Presidente Dutra, definindo aí, nesse momento, as áreas intensamente ocupadas.

A forte industrialização do município na década de 1970 se deu, entre outros fatores,

[...] à estratégica proximidade à cidade de São Paulo; à facilidade de acesso pela via Dutra; à instalação de distritos industriais e polos tecnológicos; à oferta de mão de obra qualificada e à política de incentivos fiscais (Costa, 2007, p. 32).

Entre 1970 e 1980, de acordo com Costa (2007, p. 31),

[...] a taxa de crescimento do valor da transformação industrial de São José dos Campos atingiu 15,3\% a.a. 0 volume do emprego industrial, medido pelo censo de estabelecimentos, passou, no mesmo período, de 17.786 para 41.432 empregados, com uma taxa significativamente mais alta que o crescimento da população urbana do mesmo período. Em síntese, o desempenho industrial da região assegurou taxas de crescimento muito superiores às verificadas para o conjunto do Estado.

Chuster (1999) ressalta o impacto causado pela Rodovia Presidente Dutra, comparado ao proporcionado pela abertura, em 1928, da Rodovia Washington Luiz, também ligando São Paulo e Rio de Janeiro. De acordo com o autor,

Essa rodovia causa um impacto muito diferente da antiga ligação de terra batida, até então existente, pois com um traçado mais suave e menos sinuoso, mais curto e asfaltado, fez diminuir sensivelmente o tempo de ligação entre as duas maiores metrópoles do país (Chuster, 1999, p. 2).

A área industrial anterior à ocupação do entorno da Dutra, em 1970, abrangia a região norte (Figura 3). Área que abrigou a primeira fase industrial da cidade, com início na década de 1920, a região norte perdeu proeminência com a instalação da Dutra, inaugurando uma nova centralidade urbana. É, portanto, no deslocamento desse processo que se insere a construção do mito da Maria Peregrina.

O bairro de Santana, localizado na região norte de São José dos Campos, teve início no final do século XIX em razão das atividades de tropeiros que utilizavam o lugar como caminho para Minas Gerais. Em 1868, Santana foi oficialmente reconhecido como bairro, lugar empobrecido, com pequenas casinhas e fortes características de isolamento em relação ao centro da cidade (Ramos, 2009, p. 79). No entanto, sua localização privilegiada (Figura 4), próxima ao rio Paraíba e à serra da Mantiqueira, tornou o bairro um local de permanência de tropeiros oriundos de Minas Gerais, fortalecendo o comércio na região.

Entretanto, foi a partir de 1920, sob a égide da primeira industrialização na cidade de São José dos Campos, que o bairro de Santana começou a se fortalecer como bairro industrial. Vários empreendimentos fabris foram instalados no bairro nesse período, dando início ao perfil de bairro operário que, durante muitos anos, caracterizou o bairro de Santana. Em 1925, no bairro, foi inaugurada a Tecelagem Parahyba, indústria de maior porte, que, a partir de 1933, tornou-se a referência da cidade, sendo conhecida nacionalmente (Santos, 2006, p. 46). A Tecelagem Parahyba, com sua vila operária, trouxe consigo a consolidação de Santana como bairro industrial, característica reafirmada com o zoneamento de 1938, quando se tornou zona industrial de São José dos Campos.

Em 1946, a Rhodosá de Rayon (Rhodia), grande fábrica transnacional de indústria química, se instalou no bairro. A empresa começou a funcionar em 1949, no contexto da segunda industrialização, que teve início também no bairro de Santana (Santos, 2006, p. 48). No entanto, com a inauguração da Rodovia Presidente Dutra em 1951, a região leste da cidade tornou-se a região que centralizaria, a partir dessa época, grandes conglomerados de indústrias transnacionais, como General Motors, Eaton, Embraer, entre outras.

A Via Dutra, inaugurada em 1951 como principal via de união entre dois grandes polos, São Paulo e Rio de Janeiro, transformou a região leste da cidade na mais industrializada de São José dos Campos para a época (Souza, 2008). A partir disso, o bairro de Santana, localizado na zona norte da cidade (Figura 5), começou a perder paulatinamente sua condição de 


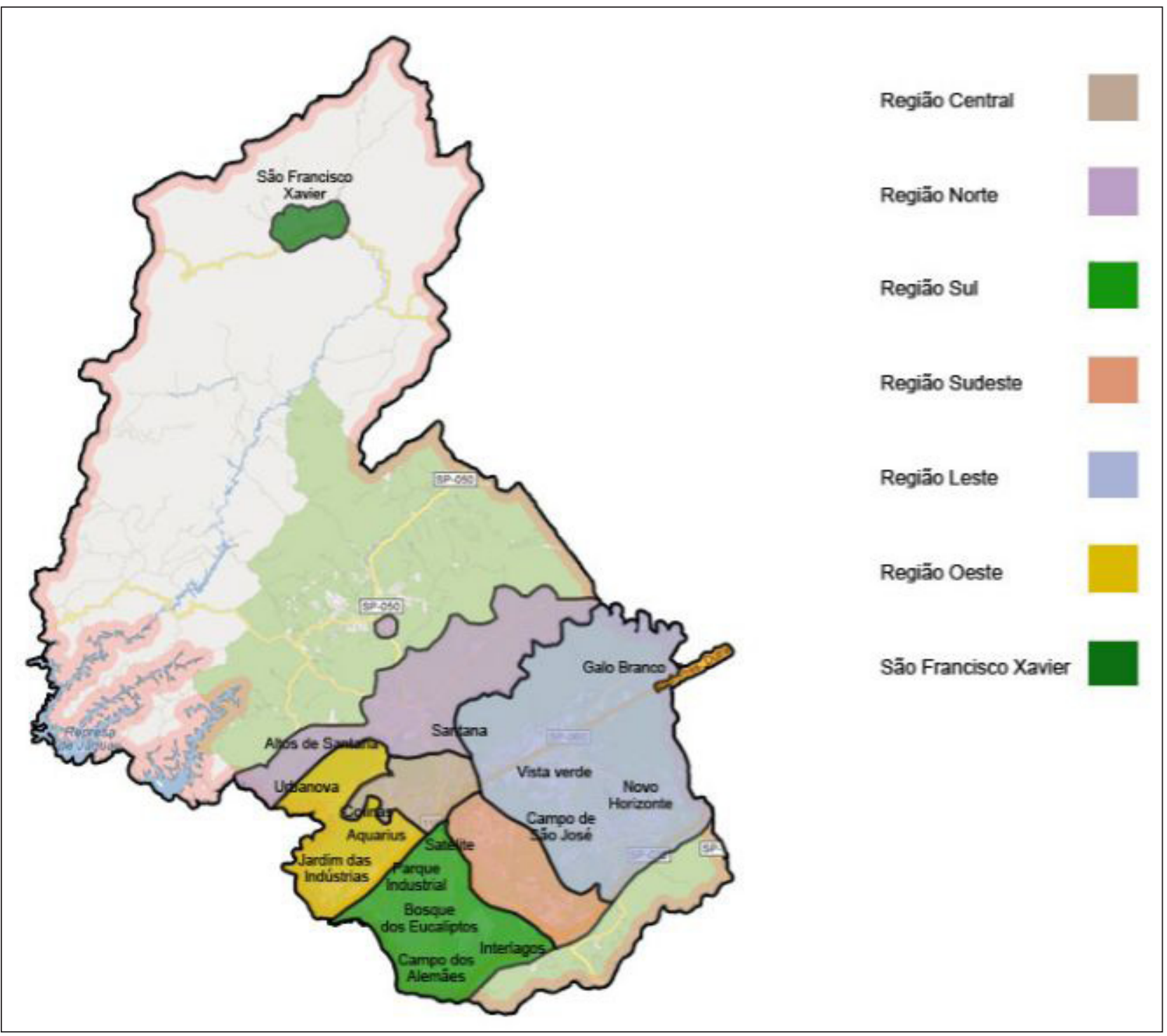

Figura 3 - Organização territorial do municíio de São José dos Campos (SP)

Fonte: Secretaria de Planejamento Urbano da Prefeitura Municipal de São José dos Campos (2016).

bairro industrial e operário, tornando-se mais apegado às tradições e mais aderente ao isolamento costumeiro. É nesse contexto (décadas de 1960/1970) que o mito da Maria Peregrina ganha força e vitalidade no bairro.

\section{Maria Peregrina: um mito em construção - Estabelecendo as conexões}

Maria Peregrina, independentemente de ser objeto de devoção, é um sujeito histórico que dá forma ao mito e reflete traços da identidade do bairro de
Santana e das suas relações com a cidade de São José dos Campos.

Quem era Maria Peregrina? Melo (1992, p. 27) descreve situações vinculadas à sua infância, quando essa mulher surgiu na vizinhança:

Eu a conheci nos últimos anos de sua vida. Foi por volta de 1946, quando, no bairro Alto da Ponte (Santana), aparecia aquela mulher negra, de estatura média, andar lento, aparentando mais ou menos 60 anos de idade, sozinha, muito maltrapilha, trazendo na cabeça um 


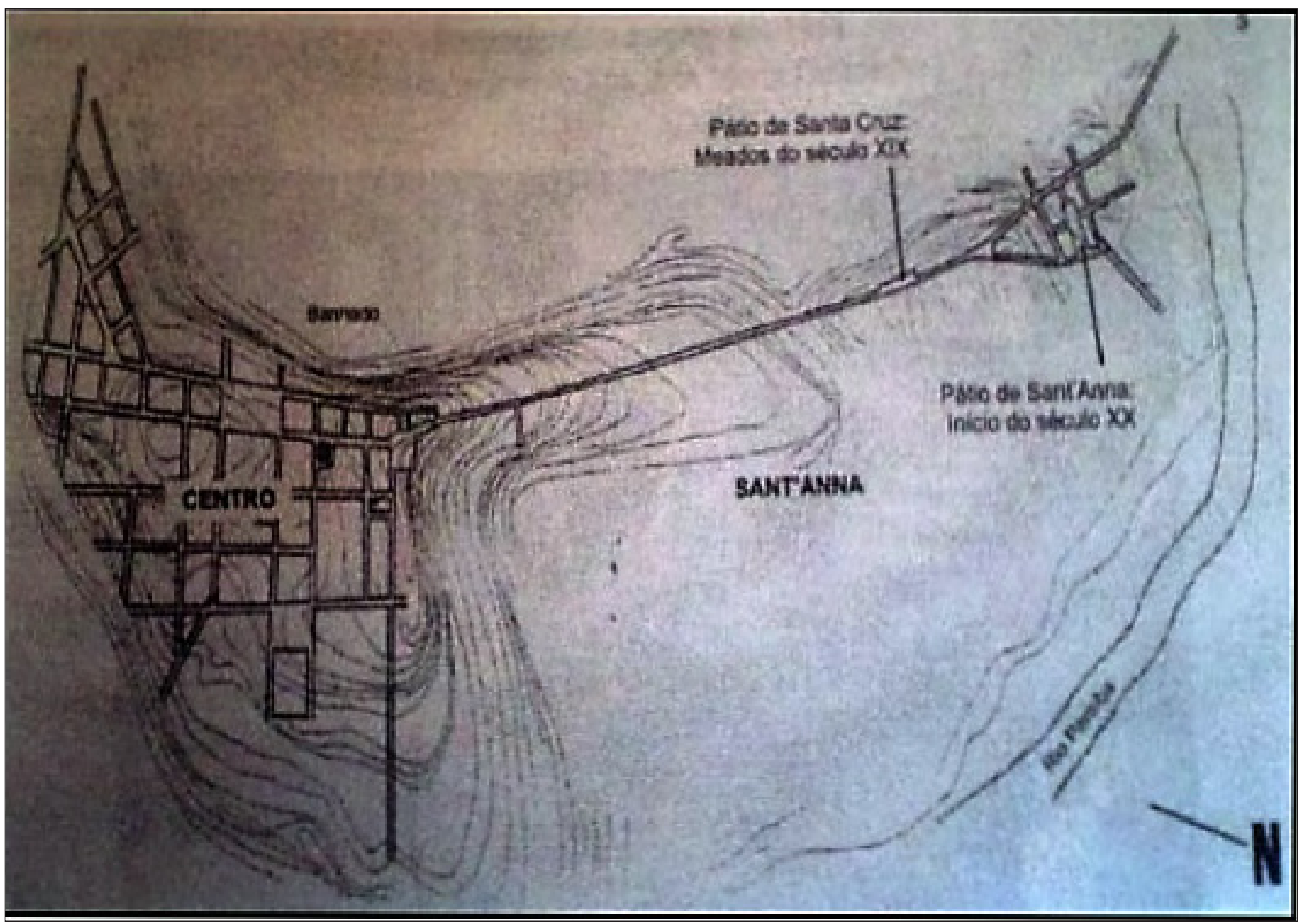

Figura 4 - Planta do centro de São José dos Campos e o bairro de Santana em 1910 Fonte: arquivo público do Município de São José dos Campos.

velho saco de estopa cheio de latas e roupas velhas.

Quando começou a peregrinar pelas ruas do bairro e da cidade, com aquele saco na cabeça, todos queriam saber seu nome, e logo souberam. Ela se chamava Maria. Era mais um Maria sofredora que o povo ficava conhecendo.

E por causa daquele saco, que carregava na cabeça, o povo logo a apelidou de 'Maria do Saco' ou 'Nega do Saco'.

As pessoas que não gostavam de apelidos e que respeitavam aquela criatura chamavam-na de Nhá Maria ou Sá Maria, mas os moleques sempre a chamavam de 'Nega do Saco'.
Outros reconhecimentos de sua importância para a vida do bairro surgem em depoimentos coletados por Martins (2011, p. 89):

Eu lembro minha mãe conversando com ela, minha avó, dando comida, a dar leite, enfim [...] a sensação que eu tinha dela é que era uma mulher muito boa. Ela punha medo nas crianças né, porque a molecada enchia a paciência.

Dado o período histórico (1960/1970) e o espaço geográfico em que a devoção se desenvolve (bairro de Santana), pode-se entender a história da Peregrina como metafórica, atuando como uma parábola de múltiplas direções, que explicita o conflito de uma sociedade marcada por uma herança cultural conservadora, perante uma cidade que, pelos idos da década de 1950, buscava formas de se modernizar. É nesse contexto que se entende a força que Peregrina teve para o espaço, após sua morte em 1964. 


\section{Município de São José dos Campos}

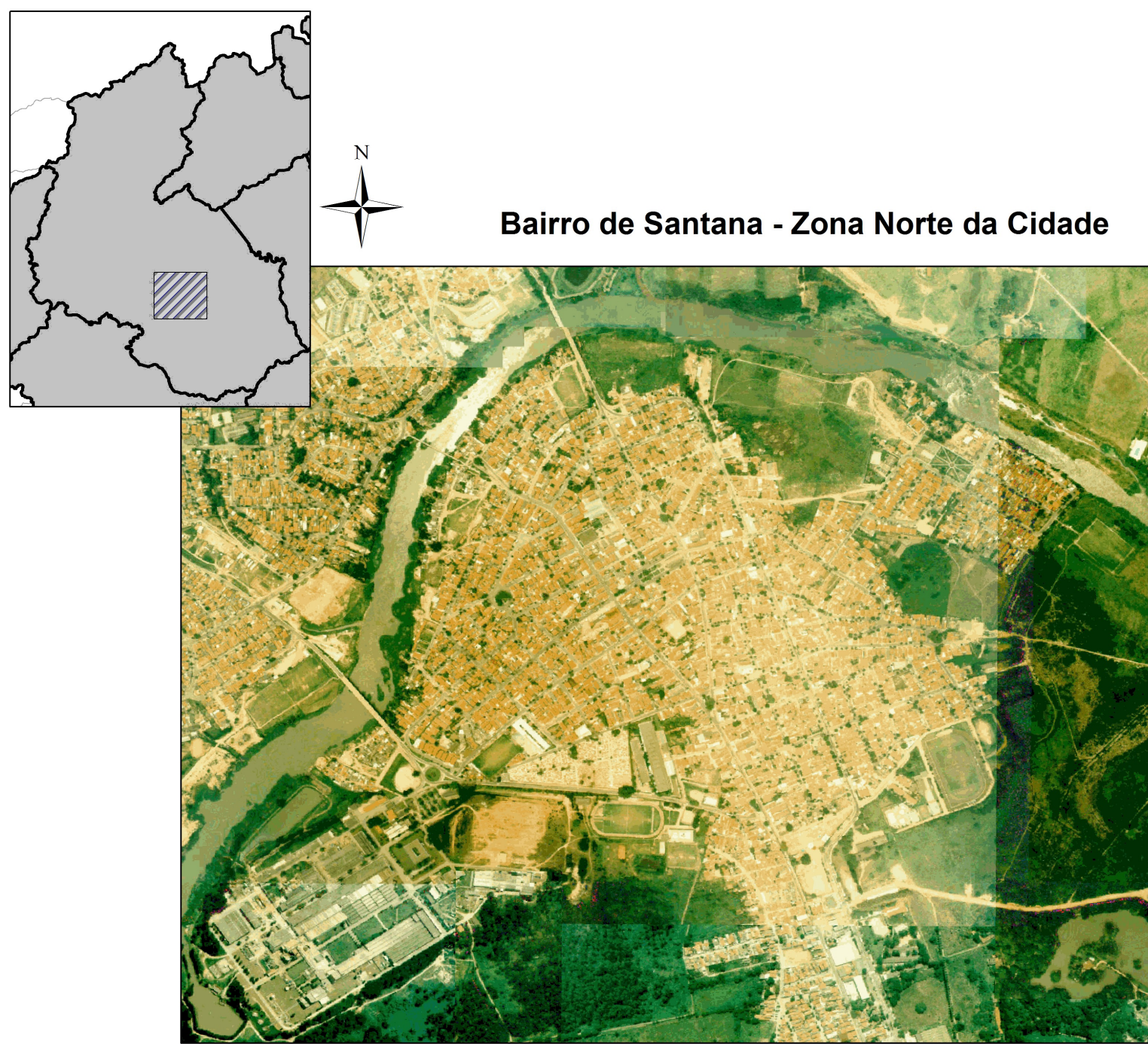

Figura 5 - Mapa do bairro de Santana, em São José dos Campos Fonte: elaborado pelas autoras.

Independentemente de Maria Peregrina ter ou não existido, a história construída sobre ela revela os anseios e as dúvidas de uma sociedade em conflito com suas próprias mudanças. Talvez esteja na ausência de história da Peregrina a justificativa para dar ao mito a interpretação múltipla e maleável que a alegoria exigia. É nesse sentido que se entende o processo de construção mítica da andarilha, como uma das respostas da comunidade às demandas do contexto histórico.
A década de 1950 é vista aqui como o momento do processo de construção mítica. Busca-se ainda discutir como e por que a mendiga Maria Peregrina adquiriu reconhecimento social e recebeu homenagens públicas, na comunidade de Santana, a ponto de seu nome ser dado ao cemitério local, em 2002, e a uma importante ponte que dá acesso à via norte.

Em relação à construção da sepultura de Maria Peregrina, Melo (1992, p. 50) afirma que uma senhora, de nome Benedita Maria das Dores, construiu seu túmulo, em gratidão a uma graça alcançada, pela 
intervenção da andarilha. Em seu túmulo, mandou gravar um epitáfio: "Aqui jaz Maria Peregrina” (Figura 6). Em 2002, o cemitério municipal, localizado no bairro de Santana, recebeu a denominação "Cemitério Maria Peregrina", de acordo com a Lei ${ }^{\circ}$ 6.184/02, de 17 de outubro de 2002 (São José dos Campos, 2002b). No mesmo ano, a ponte que liga o bairro de Santana ao bairro Telespark, sobre o Rio Paraíba do Sul, em
São José dos Campos, também recebeu seu nome, por meio da Lei Municipal $\mathrm{n}^{\circ} 6.134 / 02$, de 12 de junho de 2002 (São José dos Campos, 2002a) (Figura 7).

Acertadamente, a história do bairro responde às questões sobre a relação entre a criação do mito e os moradores do bairro. A construção desse mito relaciona-se à percepção de identidade dos moradores com o local, em um momento de rupturas, de mudanças

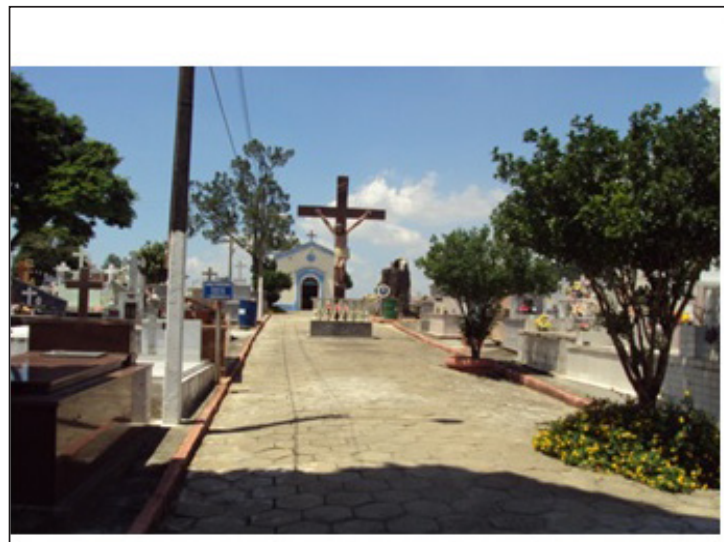

(a)

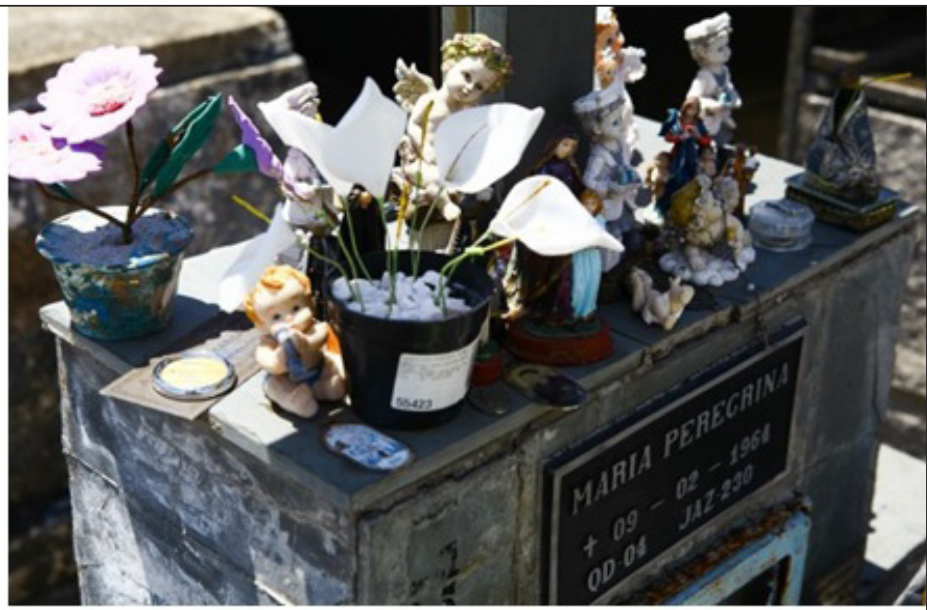

(b)

Figura 6 - Cemitério "Maria Peregrina" e o seu Túmulo, construído por Benedita Maria das Flores, um dos mais visitados no cemitério de Santana Fonte: (a) Acervo Pessoal e (b) Rodrigues \& Pereira (2014).

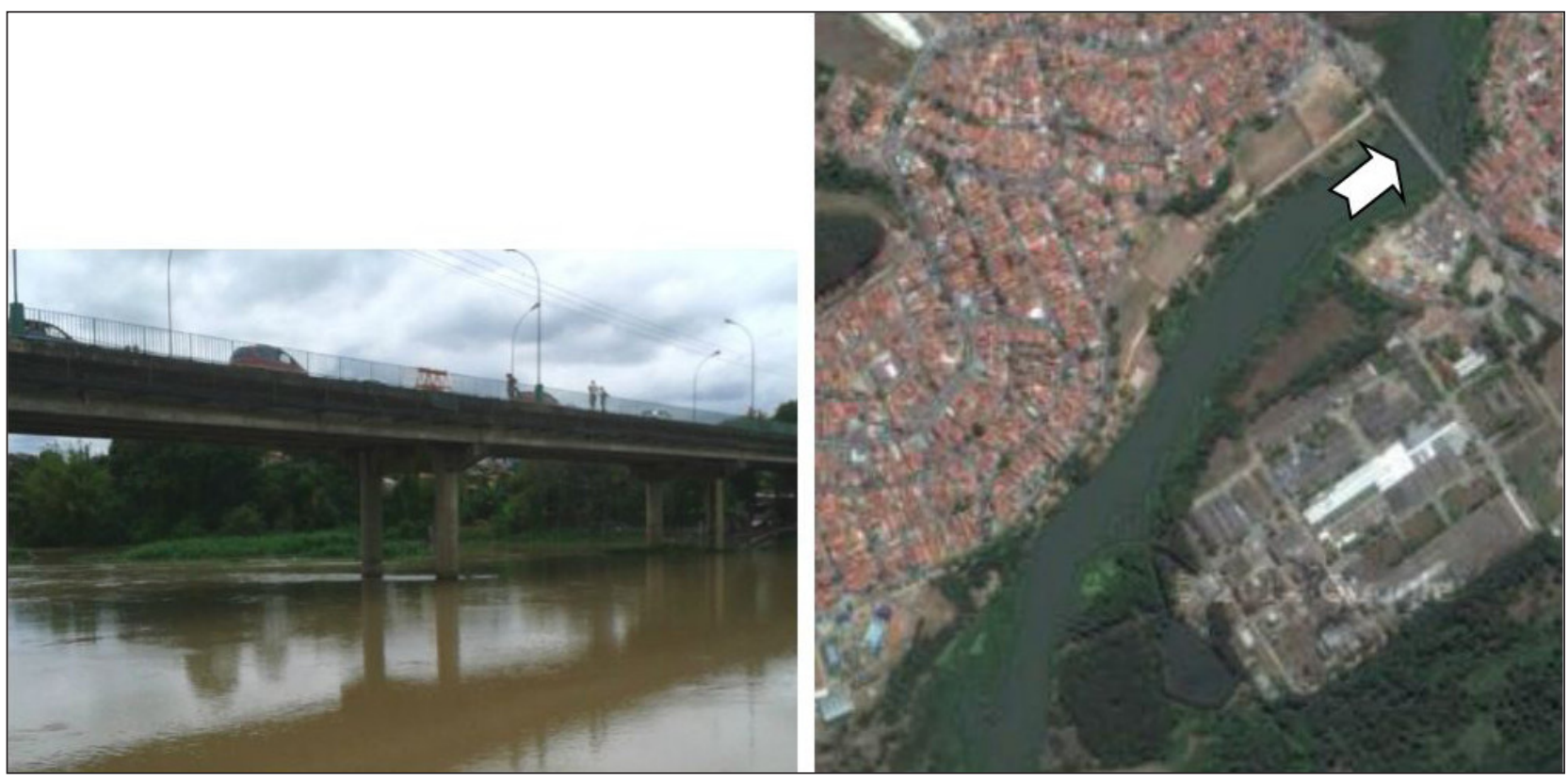

Figura 7 - (a) Ponte Maria Peregrina, em Santana, (b) e sua localização sobre o rio Parába Fonte: Google Earth (2016). 
espaciais e econômicas. A história do bairro de Santana aponta singularidades em relação ao processo histórico da cidade de São José dos Campos.

No período compreendido entre as décadas de 1920 e 1950, São José dos Campos era nacionalmente conhecida por abrigar centros para tratamento de doenças respiratórias, principalmente tuberculose. As atividades e os serviços ligados à condição de estância climática e hidromineral, concedidos pelos governos federal e estadual, em 1935, concentrados no centro da cidade, eram responsáveis por grande parte da receita do município.

De acordo com Santos (2006, p. 60), na década de 1920, havia três importantes aglomerações urbanas no município: o distrito de Eugênio de Melo, a área central da cidade de São José dos Campos e o bairro de Santana. Nessa década, ocorreram os principais eventos que desencadearam as intensas transformações do espaço urbano nas três décadas seguintes. Um evento foi a edição da Resolução n. 4 (1920), a qual "[...] estabeleceu privilégios para a instalação de estabelecimentos fabris de porte" (Santos, 2006, p. 60), em consonância com o início da descentralização industrial da cidade de São Paulo.

Santos (2006, p. 6) afirma que Santana, beneficiado também por outro evento, a mudança da estação ferroviária, que facilitava o escoamento de produtos, firma-se, então, como bairro operário e industrial, condição essa ratificada pelo zoneamento de 1938.

Durante o governo do prefeito José Domingues de Vasconcellos (1932 a 1933), foi proposta a primeira lei de zoneamento urbano do município (Ato $\mathrm{n}^{\circ} 10$, de 10 de março de 1932), como exigência para concessão do título de estância climática (Ramos, 2009, p. 17). Essa condição estabeleceu a divisão da cidade em zonas definidas por suas funções residencial, comercial, sanatorial e industrial (Ramos, 2009, p. 42-43). A região norte, que inclui o bairro de Santana, foi incorporada à zona industrial, atividade de intensa geração de renda para o município.

Santos (2006) propõe a divisão do processo de industrialização de São José dos Campos em dois momentos: a primeira industrialização (1920-1945) e a segunda industrialização (1946-2000). A primeira industrialização

[...] foi caracterizada por empreendimentos fabris liderados por capitalistas brasileiros ou imigrantes egressos de outras regiões do estado ou da capital. Eram investimentos significativos em termos de volume de capital e nível técnico, mesclando-se às fábricas familiares e pequenas oficinas existentes (Santos, 2006, p. 35).

Santos (2006) elaborou uma sequência cronológica das plantas da cidade, relacionadas à área urbanizada com a implantação de mais de 40 grandes empreendimentos industriais que permitiram assegurar a importância de São José dos Campos como polo urbanizador desempenhado pelas fábricas, na década de 1920.

Em 1925, a instalação da Tecelagem Parahyba (Figura 8), a fábrica de Louças Santo Eugênio Bonádio e, em 1935, a Cooperativa Central de Laticínios (Cooper) deram intenso destaque ao bairro de Santana. O contingente de operários aumentou significativamente, tendo se ampliado, gradativamente, nas décadas seguintes. Na década de 1930, surgiram também as primeiras moradias para funcionários graduados, diretores e operários, que compunham a população do município no início da década de 1934, com 31.606 habitantes e, em 1940, 36.279 habitantes (Santos, 2006), crescimento causado, principalmente, pela migração rural-urbana.

A segunda industrialização, que se inicia em 1946, inaugurou o momento em que as fábricas de grande porte, transnacionais e empreendimentos fomentadores da industrialização encabeçados pelo governo federal, começaram a se instalar em outras áreas do município. Nesse momento, a Rhodosá de Rayon (Rhodia) e o Centro Técnico de Aeronáutica

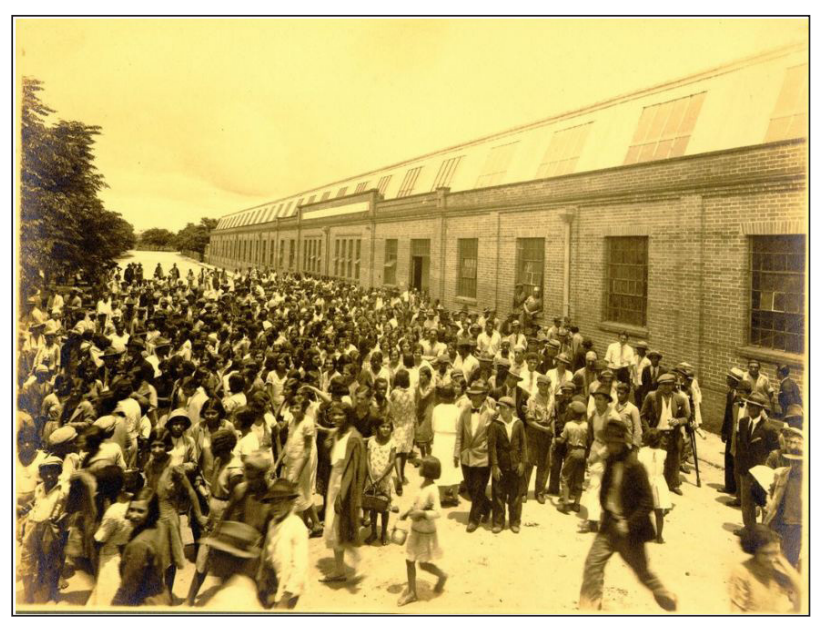

Figura 8 - Vista da Tecelagem Parahyba, em Santana (1957) Fonte: arquivo público do município de São José dos Campos (apud Ramos, 2009). 
(1947-1950) foram impulsionados pela Via Dutra, construção iniciada em 1944 e inaugurada em 1951. As novas empresas fabris, incluindo a segunda unidade da fábrica de louças e um laticínio, instalaram-se fora da então zona industrial, indicando o esgotamento das áreas de grande extensão, no bairro de Santana (Figura 9).

A Tecelagem Parahyba, fábrica dos famosos cobertores, e a Cerâmica Weiss, oficina de louças, são alguns dos estabelecimentos que se alojaram no bairro de Santana, entre as décadas de 1920 e 1940. A concentração das atividades industriais determinou a configuração espacial desse bairro, composto da vila operária, agremiações, igreja e escola. Segundo Anjos (2004, p. 56), o bairro, até esse momento estagnado, presenciou uma nova fase e foi o único núcleo urbano que manteve uma relação positiva entre o número de equipamentos públicos e o de habitantes.
A vertiginosa urbanização da cidade de São José dos Campos, a partir do final da década de 1940, é um dos casos mais significativos no Brasil, decorrente da intensa implantação de fábricas promovida pelo processo de expansão do parque industrial de São Paulo para cidades situadas em um raio de cerca de $100 \mathrm{~km}$. Essa dinâmica urbana se acirrou a partir da década de 1970, quando se tornou problemática a disponibilidade de áreas livres para a implantação fabril na capital paulista, fenômeno denominado "desindustrialização" paulistana.

Foi a partir da década de 1950, com a instalação do Centro Técnico da Aeronáutica (CTA) e da Rodovia Presidente Dutra, em 1951, que o cenário do bairro de Santana começou a ser alterado (Figura 10). As indústrias deslocaram-se da região norte da cidade de São José dos Campos para o entorno da rodovia,

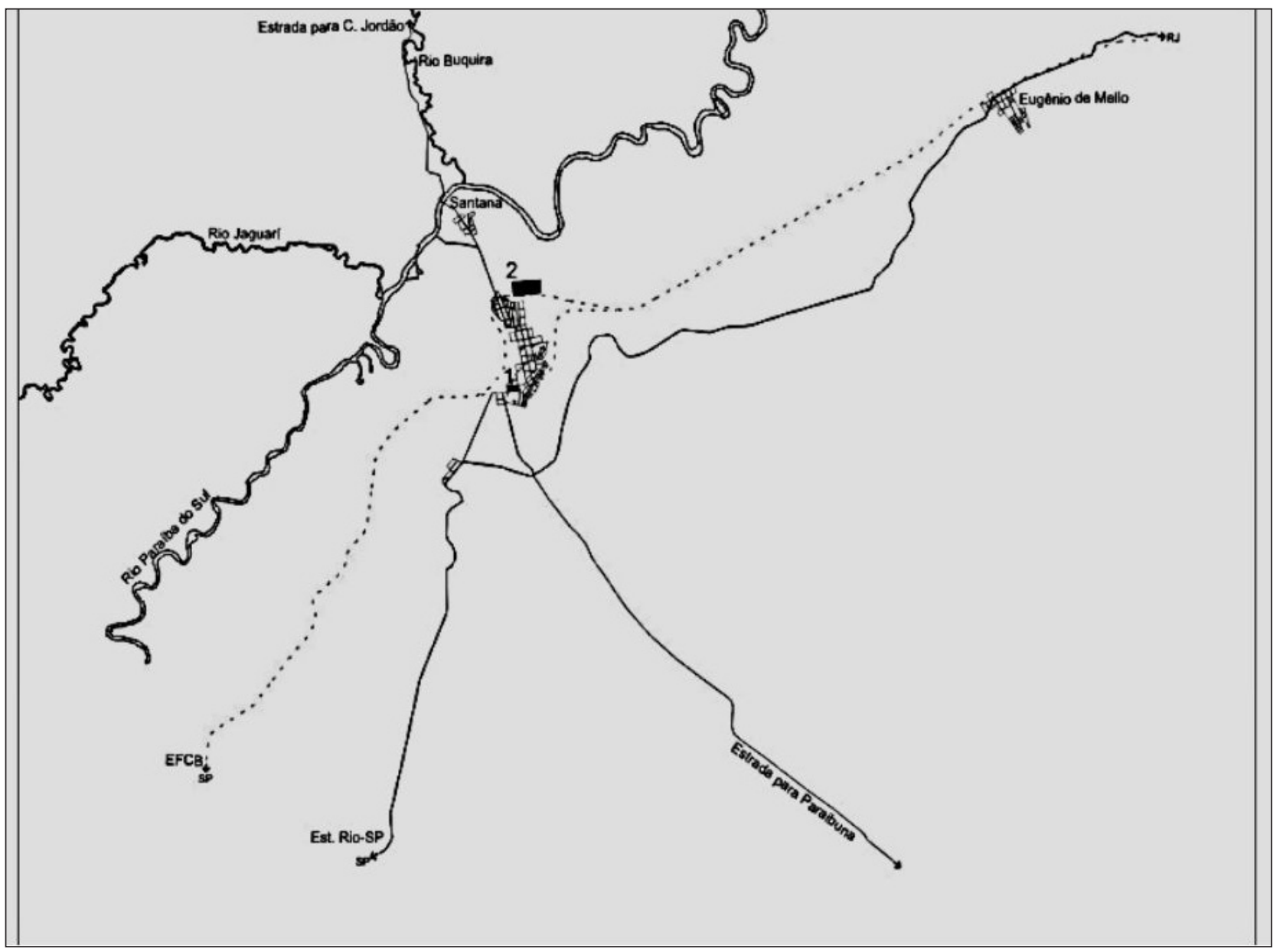

Figura 9 - Quadro da urbanizaç̃ão e indústria em São José dos Campos na década de 1920: (1) Bonádio, 1920; (2) Tecelagem Parahyba, 1925 Fonte: Santos (2006). 


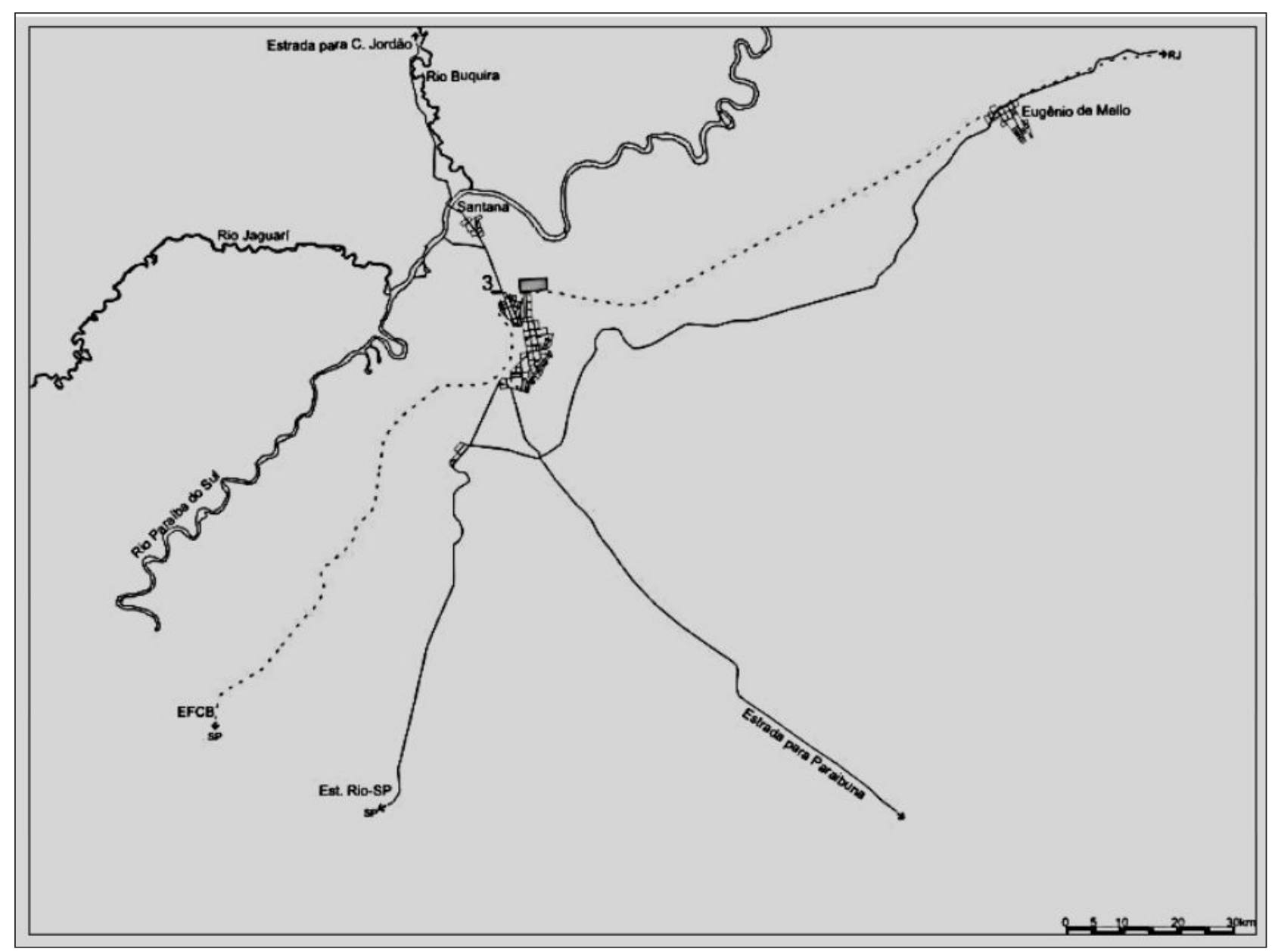

Figura 10 - Quadro da urbanização e indústria em São José dos Campos na década de 1930: (3) Cooper (1935) Fonte: Santos (2006).

principal via de conexão entre as duas metrópoles nacionais, São Paulo e Rio de Janeiro.

Por sua vez, o CTA permitiu à cidade desenvolver seu complexo tecnológico industrial aeroespacial (Plano Diretor de Desenvolvimento Integrado - PDDI/ São José dos Campos, 1994, p. 33). Para Santos (2006, p. 122), sua construção transformou São José dos Campos em polo industrial "[...] de ponta, e deu uma nova fisionomia para a cidade, projetando-a em nível nacional como a 'cidade do avião'”. Tais mudanças provocaram alterações significativas nas estruturas política, econômica e social da região norte da cidade, que deixou de ser, a partir disso, o referencial industrial do município (Figura 11).

A partir de 1950, o bairro perdeu a hegemonia industrial e teve uma dispersão populacional, pois as residências dos trabalhadores acompanhavam a instalação das indústrias, às margens da rodovia
Presidente Dutra (Figura 12). Conforme ressaltou Certeau (1982), nos momentos de dispersão é que se buscam os elementos de coesão, como forma de afirmação e projeção de identidades.

Maria Peregrina foi um elemento capaz de reorganizar a comunidade que se expandia, se desagregava e se modificava. Trata-se, pois, de uma forma de representar as contradições da modernidade, que se mostra capaz de reaproximar a comunidade em expansão e garantir a diferenciação dos grupos sociais de Santana em relação ao restante da cidade. 0 mito age, portanto, como elemento de coesão interna, ao mesmo tempo que se firma como símbolo de diferenciação entre bairro e cidade.

De acordo com Kevin Lynch (apud Costa \& Maciel, 2009, p. 63), a concepção que os indivíduos têm de um bairro está relacionada a uma série de imagens que se relacionam, por sua vez, ao significado social 


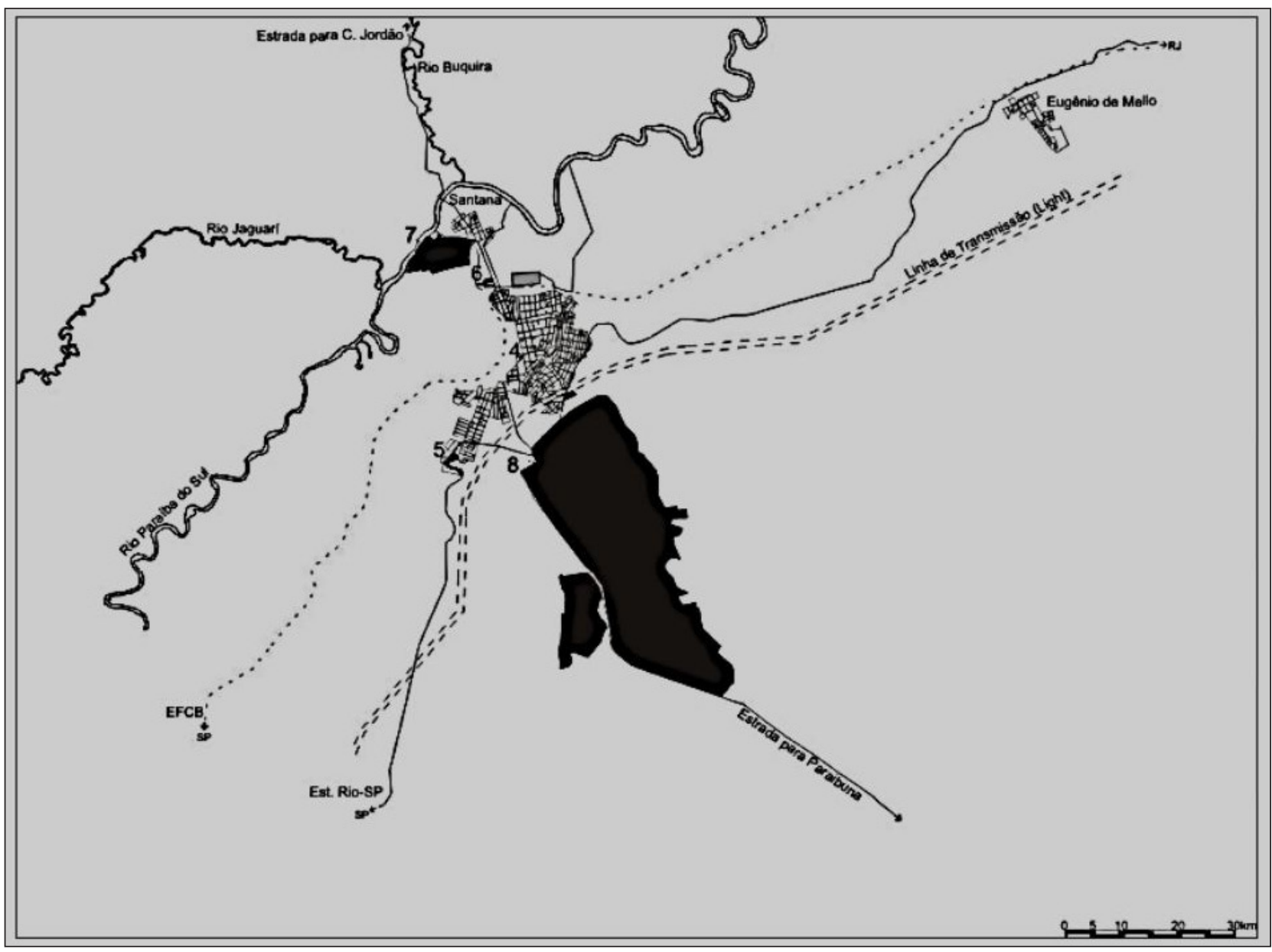

Figura 11 - Quadro da urbanização e indústria em São José dos Campos, na década de 1940: (4) Cerâmica Weiss I (1941); (5) Vigor (1943); (6) Cerâmica Weiss II (1944); (7) Rhodia (1946); (8) Centro Técnico de Aeronáutica (CTA) (1947) Fonte: Santos (2006).

de determinada região, à sua função dentro da cidade, à sua história e ao seu nome, entre outras coisas. De acordo com Halbwahcs (apud Costa \& Maciel, 2009, p. 63),

[...] todas as ações do grupo podem ser traduzidas em termos espaciais, o lugar por ele ocupado é apenas a reunião de todos os termos. Cada aspecto, cada detalhe desse lugar tem um sentido que só é inteligível para os membros do grupo, porque todas as partes do espaço que ele ocupou correspondem a outros tantos aspectos diferentes da estrutura e da vida de sua sociedade.

Após 1950, as mudanças ocorridas em Santana alteraram as imagens e modificaram o significado social da região, que, de acordo com Lynch, definiam o bairro e sua função dentro da cidade. Essa transformação alterou, portanto, o sentido pelo qual o bairro era percebido.

O mito da Peregrina surgiu de uma necessidade premente, relacionada à percepção da identidade de grupo, em um momento de rupturas e transformações. A carência de fontes, que, a princípio, significou um impedimento para a construção da alegoria sobre Maria Peregrina, favoreceu as possibilidades de identificações coletiva e individual. A falta de dados sobre Peregrina tornou o mito adaptável e permitiu que a construção mítica se utilizasse de símbolos e imagens que compuseram o imaginário local, para adquirir força e representatividade. 


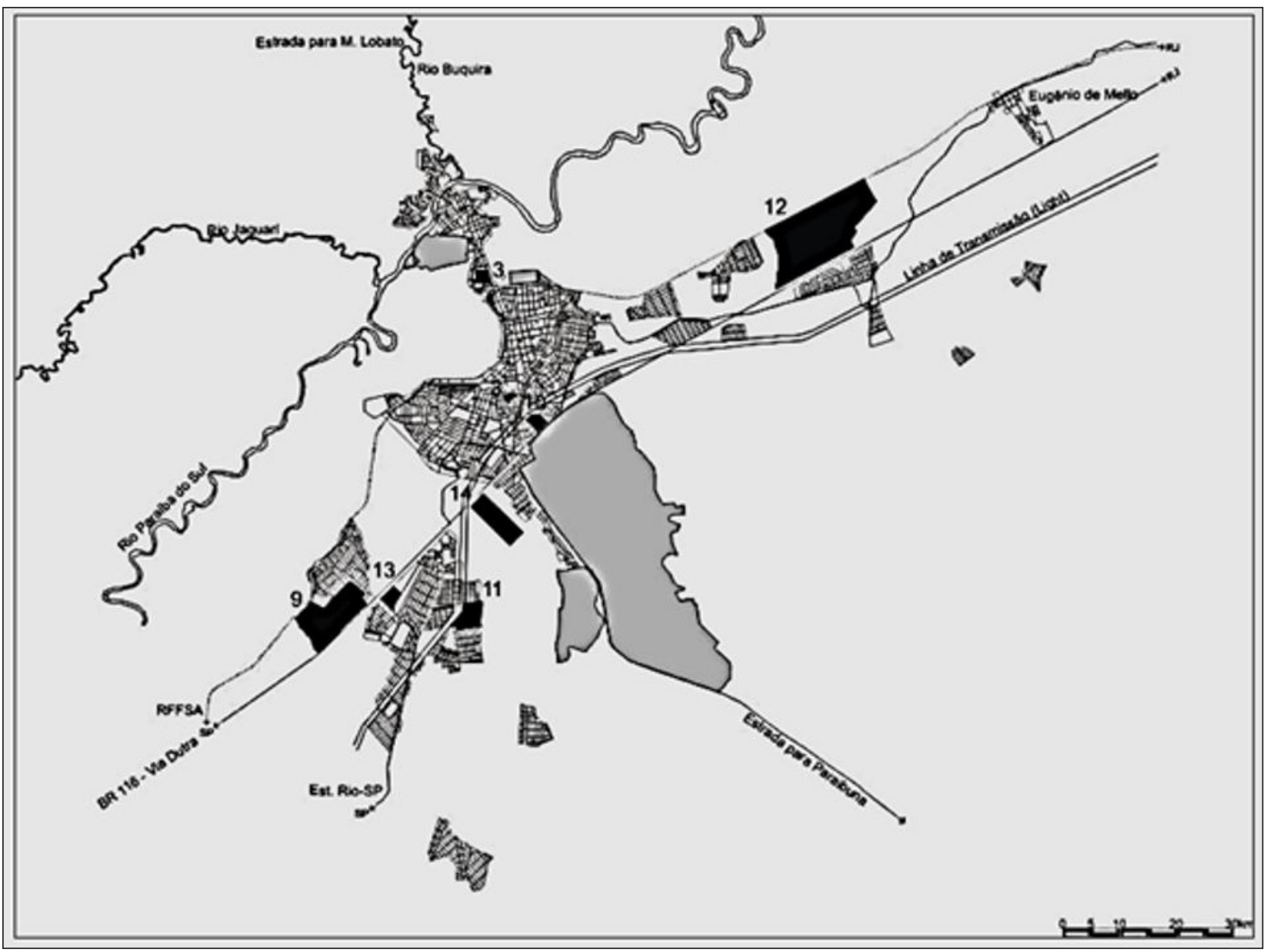

Figura 12 - Quadro da urbanização e indústria em São José dos Campos, na década de 1950. (3) Cooper (1957); (9) Johnson \& Johnson (1954); (10) Ericsson I (1954); (11) Kanebo (1956); (12) General Motors (1957); (13) Eaton (1957); (14) Alpargatas (1959) Fonte: Santos (2006).

\section{Considerações finais}

Pensar historicamente a devoção à Maria Peregrina é reconhecer a pluralidade de sentidos atribuídos ao mito. Seja ou não compreendida como "santa", Maria Peregrina é uma expressão cultural articulada ao contexto histórico, que reflete as representações, as práticas e as visões de mundo de uma comunidade espacialmente referenciada.

A "transformação" de um indivíduo em mito, em santo popular, é um fenômeno com múltiplas possiblidades de análise, resposta ao diálogo travado entre as diferentes áreas do conhecimento como a história cultural, a antropologia, a sociologia e a geografia urbana.
Na dinâmica da nova sociedade urbana pós-1950, passado e novos valores se entrecruzam, ressignificam-se e influenciam-se mutuamente. De acordo com Gaeta (1999, p. 72-73),

[...] as devoções construídas popularmente e cristalizadas na memória coletiva, embora parasitárias do mito e da oralidade, possibilitam uma experiência do sagrado. Sinalizam que os homens de Deus, na cultura popular, escapam às conformações, permitindo que os fiéis inventem o seu próprio cotidiano e que esse processo de santificação popular é tão eficaz e legítimo quanto o efetuado pelo Vaticano [...]. Os 'santos' locais, sendo eleitos pelos moradores, constituem-se numa pertença da cidade e não 
dos altares eclesiais [...]. 0 caráter leigo, anônimo, secular, que não exige profissão de fé, permite ainda que essas 'santidades' sejam incorporadas por indivíduos de diferentes camadas sociais e mesmo por políticos regionais que, na sua individualidade, frequentam os túmulos efetuando seus apelos [...]. Esta privatização religiosa transforma-se, muitas vezes, em canais de expressão da subjetividade em que o individual prevalece sobre o coletivo e a experiência pessoal predomina sobre a doutrina, adequando-se, neste sentido, ao individualismo típico das sociedades modernas.

Conclui-se, portanto, que a industrialização joseense pós-1950 criou uma conjuntura socioeconômica que ocasionou alterações na estrutura sociocultural da comunidade da região norte, especialmente no bairro de Santana. Nesse contexto, a hagiografia de Maria Peregrina, com suas cisões e discordâncias, é, portanto, o registro simbólico de grupos distintos e das mudanças vivenciadas por eles.

Os relatos existentes sobre Peregrina são expressão de um "ideal", da projeção de anseios da população e da força religiosa que impera no bairro. Certeau (1982, p. 266) ressalta que

[...] a vida de santo é a cristalização literária das percepções de uma consciência coletiva [...] a combinação de atos, lugares e temas indica uma estrutura própria, que se refere não essencialmente "aquilo que se passou", como faz a História, mas "aquilo que é exemplar".

Os relatos sobre a Peregrina nada mais são que expressões da realidade do grupo que a elegeu santa e que revelam traço de sua cultura e visão de mundo. De acordo com Certeau (1982, p. 269),

[...] a vida de um herói/santo se inscreve na vida de um grupo, Igreja ou comunidade. Ela supõe que o grupo já tenha uma existência. Mas representa a consciência que o grupo tem de si mesmo, associando uma imagem a um lugar [...]. Assume uma distância com relação às origens (uma comunidade já constituída se distingue do seu passado graças à distância que constitui a representação desse passado). Mas, por outro lado, um retorno às origens permite reconstituir uma unidade no momento em que, desenvolvendo-se, o grupo arrisca se dispersar. Assim como a lembrança (objeto cuja construção está ligada ao desaparecimento dos começos) se combina com a "edificação" produtora de uma imagem destinada a proteger o grupo contra a dispersão. Assim se diz um momento da coletividade partilhada entre o que ela perde e o que ela cria.

Sendo assim, pressupõe-se que Maria Peregrina, ao ser adotada como "santa", tem a função de manter a consciência de grupo, capaz de representar a comunidade, atuando como elemento aglutinador: "[...] um retorno às origens (que) permite reconstituir uma unidade" (Certeau, 1982, p. 269).

0 bairro de Santana, em São José dos Campos, que, a partir da década de 1960, se descaracteriza como bairro industrial da cidade, ocasião em que o setor industrial foi transferido para a zona leste do município, encontra na construção da figura mítica de Maria Peregrina o elo capaz de recriar uma identidade para o bairro. Imbuído da religiosidade católica oriunda de suas raízes mineiras e tradicionais, o bairro de Santana busca na construção do mito da "santa" Maria Peregrina uma representação capaz de congregar toda uma comunidade. Preterido como zona industrial, o bairro de Santana se reinventa, buscando, na tradição e na religiosidade, referências capazes de novamente singularizar a região e conferir sentidos aos seus moradores.

\section{Referências}

Anjos, M. I. (2004). Análise do processo de ocupação urbana em São José dos Campos, aferindo o papel das políticas públicas na produção do espaço (Dissertação de mestrado). Instituto de Pesquisa e Desenvolvimento, Universidade do Vale do Paraíba, São José dos Campos.

Bittencourt, T. M. M. (1998). Arquitetura sanatorial - São José dos Campos. São José dos Campos: Unidades Gráficas e Editora Ltda.

Campos, C. M., Fo. (1992). Cidades Brasileiras seu controle ou caos. São Paulo: Nobel.

Certeau, M. (1982). Uma variante: a edificação hagiográfica. In P. Burke (Org.), A escrita da História. São Paulo: Editora da Universidade Estadual Paulista. Recuperado em 20 de agosto de 2009, de http://edmundomonte. com.br/wp-content/uploads/2015/02/A-Escrita-dahist\%C3\%B3ria_Michel-de-Certeau.pdf 
Chuster, V. (1999). O zoneamento em São José dos Campos: 1971-1997 (Dissertação de mestrado). Instituto de Pesquisa e Desenvolvimento, Universidade do Vale do Paraíba, São José dos Campos.

Costa, P. E. O. (2007). Legislação Urbanística e crescimento Urbano em São José dos Campos (Dissertação de mestrado). Faculdade de Arquitetura e Urbanismo, Universidade de São Paulo, São Paulo.

Costa, S. L., \& Maciel, T. M. F. B. (2009). Os sentidos da comunidade: a memória de bairro e suas construções intergeracionais em estudos de comunidade. Arquivos Brasileiros de Psicologia, 61(1), 60-72. Recuperado em 26 de maio de 2016, de http://pepsic.bvsalud.org/pdf/ arbp/v61n1/v61n1a07.pdf

Dosse, F. (2003). A história em migalhas: dos Annales à Nova História. São Paulo: Ensaio.

Gaeta, M. A. J. V. (1999). "Santos" que não são santos: estudos sobre a religiosidade popular brasileira. Mimesis, 20(1), 57-76.

Google Earth. Maps. (2016). Imagem da cidade de São José dos Campos. Recuperado em 30 de maio de 2016, de https:// www.google.com.br/maps/@-23.1551678,-45.898793,3128m/ data $=! 3 \mathrm{~m} 1 ! 1 \mathrm{e} 3$

Instituto Brasileiro de Geografia e Estatística - IBGE. (2014). Contagem populacional. Rio de Janeiro: IBGE. Recuperado 5 de setembro de 2014, de www.ibge.gov.br Le Goff, J. (1990). História e memória. Campinas: Unicamp. Martins, N. (2011). Dimensões e estratégias da mitologia urbana: uma interpretação histórica de devoção à Maria Peregrina em São José dos Campos - SP (1930 e 1970) (Trabalho de conclusão de curso). Faculdade de Educação e Artes, Universidade do Vale do Paraíba, São José dos Campos.

Martins, N., \& Braga, A. C. (2009). Entre o mito e a fé: a devoção à Maria Peregrina em São José dos Campos. In Anais do XIII Encontro Latino Americano de Iniciação Científica - INIC 2009 (p. 1-3). São José dos Campos: UNIVAP.

Martins, N., \& Zanetti, V. (2011). Espaço urbano e identidade: uma interpretação histórica e geográfica da devoção á Maria Peregrina em São José dos Campos - SP (1930-1960). In Anais do XV Encontro Latino Americano de Iniciação Científica - INIC 2011 (p. 1-3). São José dos Campos: UNIVAP.

Melo, B. J. (1992). Maria Peregrina (Caderno de Folclore, No 6). São José dos Campos: Fundação Cultural Cassiano Ricardo.

Moraes, A. C. R. (1988). Ideologias geográficas: espaço, cultura e política no Brasil. São Paulo: Hucitec.

Ramos, W. S. (2009). Políticas de Zoneamento e seus reflexos no urbano: um estudo do bairro de Santana, São José dos Campos entre 1920 e 1950 (Dissertação de mestrado). Universidade do Vale do Paraíba, São José dos Campos.

Rodrigues, E., \& Pereira, F. (2014). Ensaio fotográfico: a fé e a saudade de cada Dia de Finados em São José. Recuperado em 5 de dezembro de 2015, de http://www. meon.com.br/noticias/regiao/ensaio-fotografico-a-fe-ea-saudade-de-cada-dia-de-finados-em-sao-jose

Santos, A. P. (2006). São José dos Campos: Arquitetura Industrial. São José dos Campos: Edição do autor.

Santos, M. (2004). Pensando o espaço do homem. São Paulo: Edusp.

São José dos Campos. Prefeitura Municipal (1994). PDDI Plano Diretor de Desenvolvimento Integrado. São José dos Campos: Prefeitura. Recuperado em 20 de maio de 2011, de http://www.sjc.sp.gov.br/saj/downloads/legislacao/ caderno_tecnico_pl_diretor.pdf

São José dos Campos. Prefeitura Municipal (2002a). Lei $n^{\circ}$ 6.134/02, de 12 de junho de 2002. Denomina a ponte construída sobre o Rio Paraíba, entre os Bairros Vila Rhodia e Jardim Telespark de Maria Peregrina. São José dos Campos: Prefeitura Municipal.

São José dos Campos. Prefeitura Municipal (2002b). Lei $n^{\circ}$ 6.184/02, de 17 de outubro de 2002. Denomina o Cemitério Municipal do Bairro de Santana de Cemitério Municipal Maria Peregrina. São José dos Campos: Prefeitura Municipal.

São José dos Campos. Prefeitura Municipal. Secretaria de Planejamento Urbano (2016). Organização Territorial. São José dos Campos: Prefeitura. Recuperado em 5 de maio de 2016, de http:// http://www.sjc.sp.gov.br/sao_jose/ regioes_da_cidade.aspx

Souza, A. A. M. (2008). A especialização do lugar: São José dos Campos como centro da tecnologia Aeroespacial 
no país (Tese de doutorado). Universidade de São Paulo, São Paulo.

Souza, M. A. A. (1994). A identidade da metrópole: a verticalização em São Paulo. São Paulo: Hucitec.
Zanetti, V. (2010). Cidade e Identidade: São José dos Campos, do peito e dos ares. São Paulo: Annablume.

Recebido: Mar. 17, 2016

Aprovado: Jun. 14, 2016 